\title{
Soil Moisture Monitoring System in Arugula Plants (Eruca Sativa) Using Microcontroller Esp8266 NodeMCU
}

\author{
Bisman Perangin-angin ${ }^{1}$ and Hartono Simanjuntak ${ }^{2}$ \\ ${ }^{1,2}$ Department of Physics, Faculty of Mathematics and Natural Science, Universitas Sumatera Utara, \\ Medan 20155, Indonesia
}

\begin{abstract}
The Internet of Things (IoT) is getting great attention from researchers nowadays, as it becomes an important technology that promises intelligent human life, with between objects, machines and everything together with people. IoT represents a system consisting of real-world things, and sensors attached to or combined with these things, connected to the internet through cable and wireless network structures. With IoT, the world will be smart in every aspect because IoT will provide smart city facilities, smart health care, smart homes and buildings, in addition to many important applications such as smart energy, grid, transportation, waste management and monitoring. One microcontroller device that supports the use of IoT is the Esp8266 NodeMCU integrated with the Blynk application. So that with the design of a system to control/monitor the condition or moisture of the soil in arugula plants, the cultivation or production can be more maximal and efficient.
\end{abstract}

Keyword: Arugula, IoT, Esp8266 NodeMCU, Blynk.

Received 19 August 2021 | Revised [23 August 2021] | Accepted [27 August 2021]

\section{Introduction}

Eruca Sativa originated in the Mediterranean and is known by its common name: Rocket, True Rocket, Salad Rocket, Arugula, Rouette/Rukola, or White Pepper. Eruca Sativa is used in traditional medicine for therapy as an astringent, aphrodisiac, diuretic, digestive, emollient, tonic, depurative, laxative, polluter and stimulant [1]. This young plant is used as a salad, vegetable, or green feed. E. sativa contains derivatives of isotiosinat, butane, hexane, octane, and nonane which are typical aromas of plants. Glucosinolate is found in Brassicaceae which has anticarcinogenic, anti-fungal, anti-bacterial, and antioxidant activity. Researchers are interested in research on the intake of certain foods from essential nutrients such as "Nutraceuticals" to treat or prevent disease or chronic disease risk [2]-[3]. Seed lender E. sativa reportedly has great potential as a commercial hydrocooloid in the food industry.

\footnotetext{
*Corresponding author at: Jalan Biolteknologi no.1 Medan, 20155, Indonesia

E-mail address: bisman@usu.ac.id
} 
The Internet of Things or IoT is a system of interconnected computing devices, mechanics and digital machines, objects, animals or people provided with unique identifiers (UIDs). In addition, the Internet of Things or IoT can be defined as the ability to transfer data over a network without requiring human or human-computer interactions. The Internet of Things (IoT) has also been applied in various fields, such as transportation, medicine, and manufacturing [4][10].

Eruca sativa plant is an herbal plant with fiber, protein, vitamin A, B complex, $\mathrm{C}$, and $\mathrm{K}$ that can be consumed as salads and other processed. Rukola can grow at high altitudes and low environmental temperatures. In general, Rukola can grow well on soil types that have a sandy clay texture with water content optimization of $20 \%-40 \% \mathrm{Bb}$ (wet base) and moderate light intensity. Rukola plants are very susceptible to excess and lack of water. The discursion of growth in Rukola plants as well as death can result in root decay and dryness. This is indicated by the provision of irrigation traditional systems applied by farmers to provide water without a dose that is in accordance with the needs of the crop. Therefore, it is necessary to make instruments that are able to measure groundwater content quickly and accurately and controlled irrigation is needed in accordance with the needs of each plant to increase the production of Rukola plants [11]-[15].

\section{Methods}

The block diagram of the designed system is as shown in the following image:

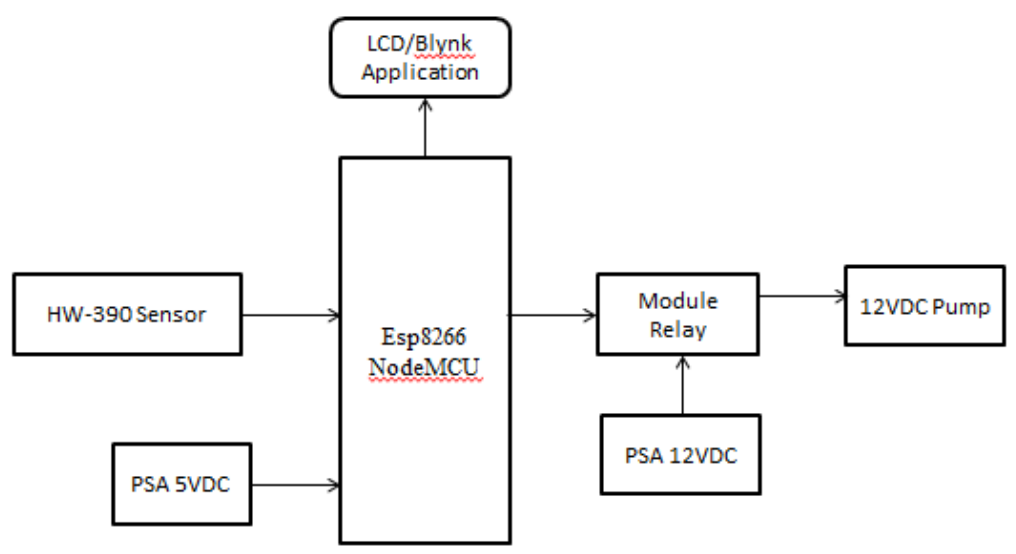

Figure 1. Block Diagram of the system

Explanation of the Function of Each Block from a Block Diagram

1. HW-390 Sensor Block : sensors to measure groundwater content (capacitive value).

2. Relay Block : Logic function and to give a delay of time.

3. Pump Block : Pumping water to the ground.

4. PSA Block : voltage sources for microcontrollers and pumps.

5. Esp8266 NodeMCU Block : The data processor of the sensor and the results are sent to the LCD/Blynk application. 
6. LCD block/Blynk application: display to display percent soil moisture.

\subsection{Complete network of plans}

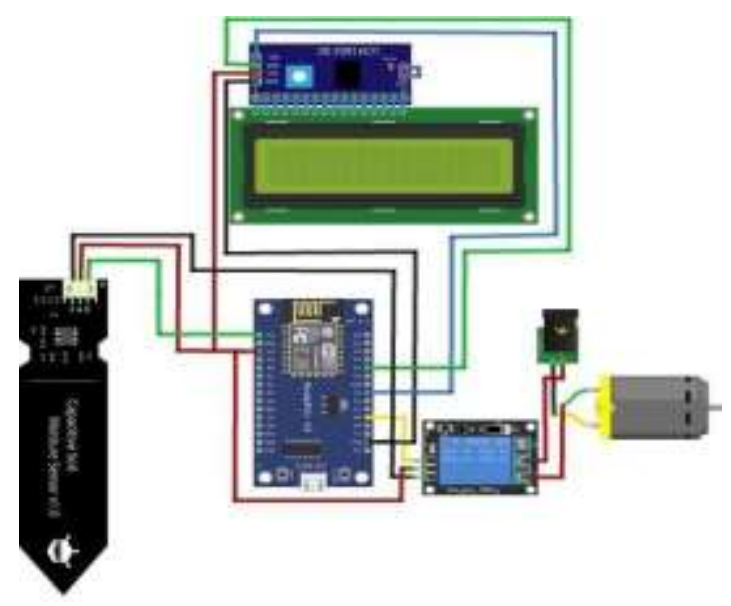

Figure 2. Complete network of plans

\subsection{System Flow Diagram}

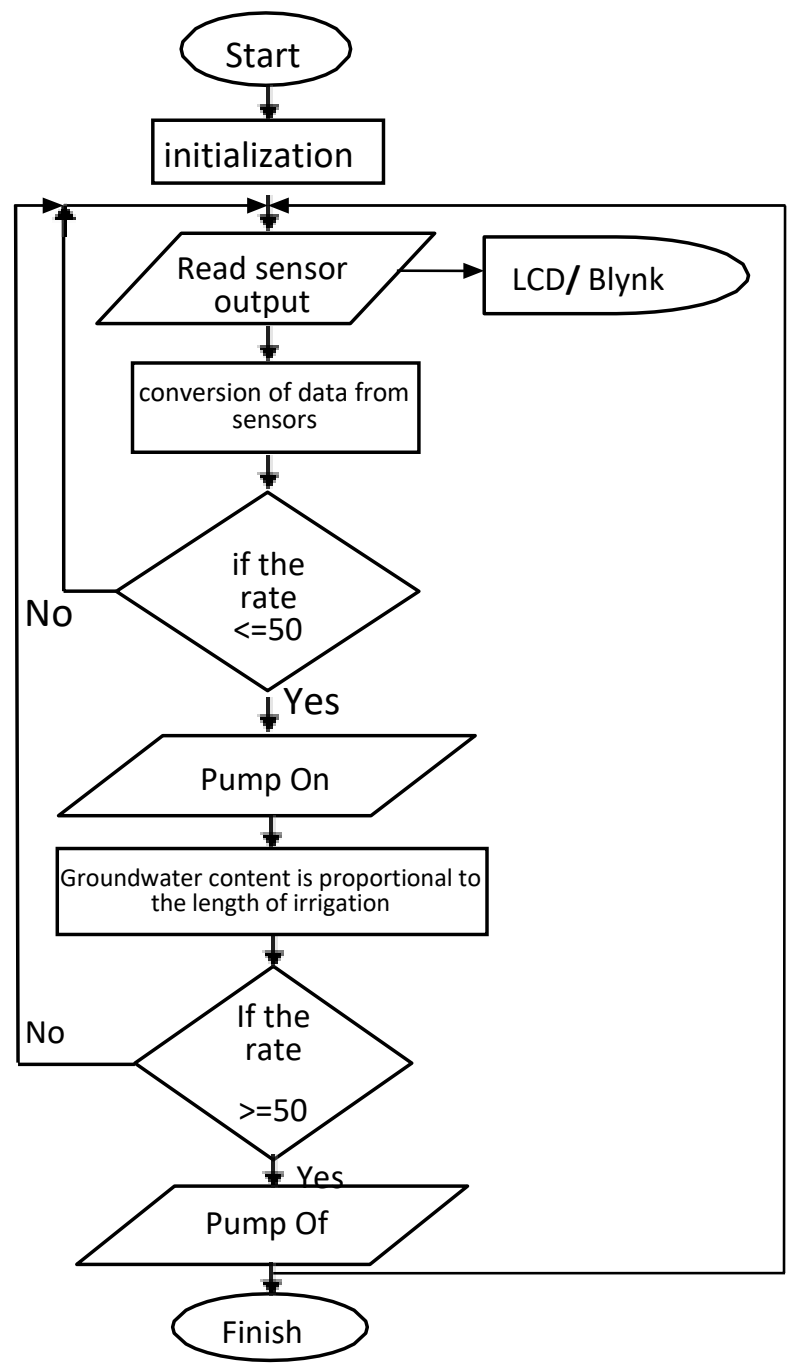

Figure 3. Flowchart of the system 


\section{Result and Discussion}

\subsection{HW-390 Sensor Testing}

In testing the HW-390 sensor, researchers conducted a test by inserting a program into the HW390 sensor to find out whether the sensor worked or not [16]-[18], here are the details of the program.

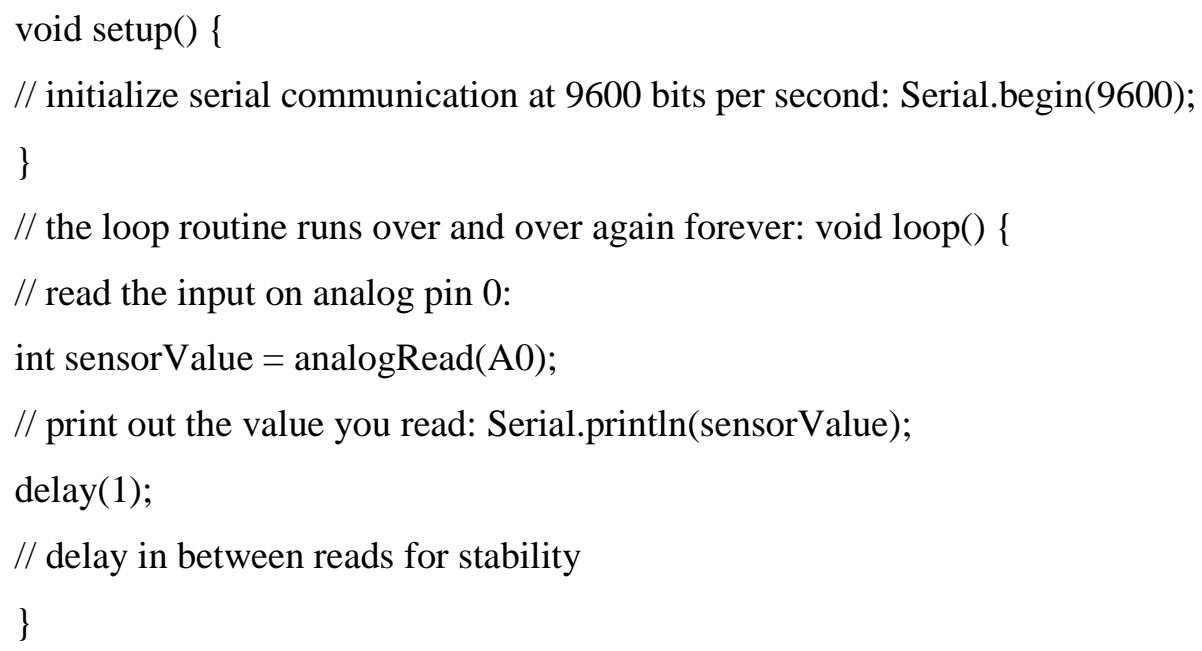

\subsection{Microcontroller Testing Esp8266 NodeMCU}

Testing in microcontroller is done by inserting a program so that this condition can be known whether it is functioning properly and connected to the internet network or not [19][20]. Here are the details of the program.

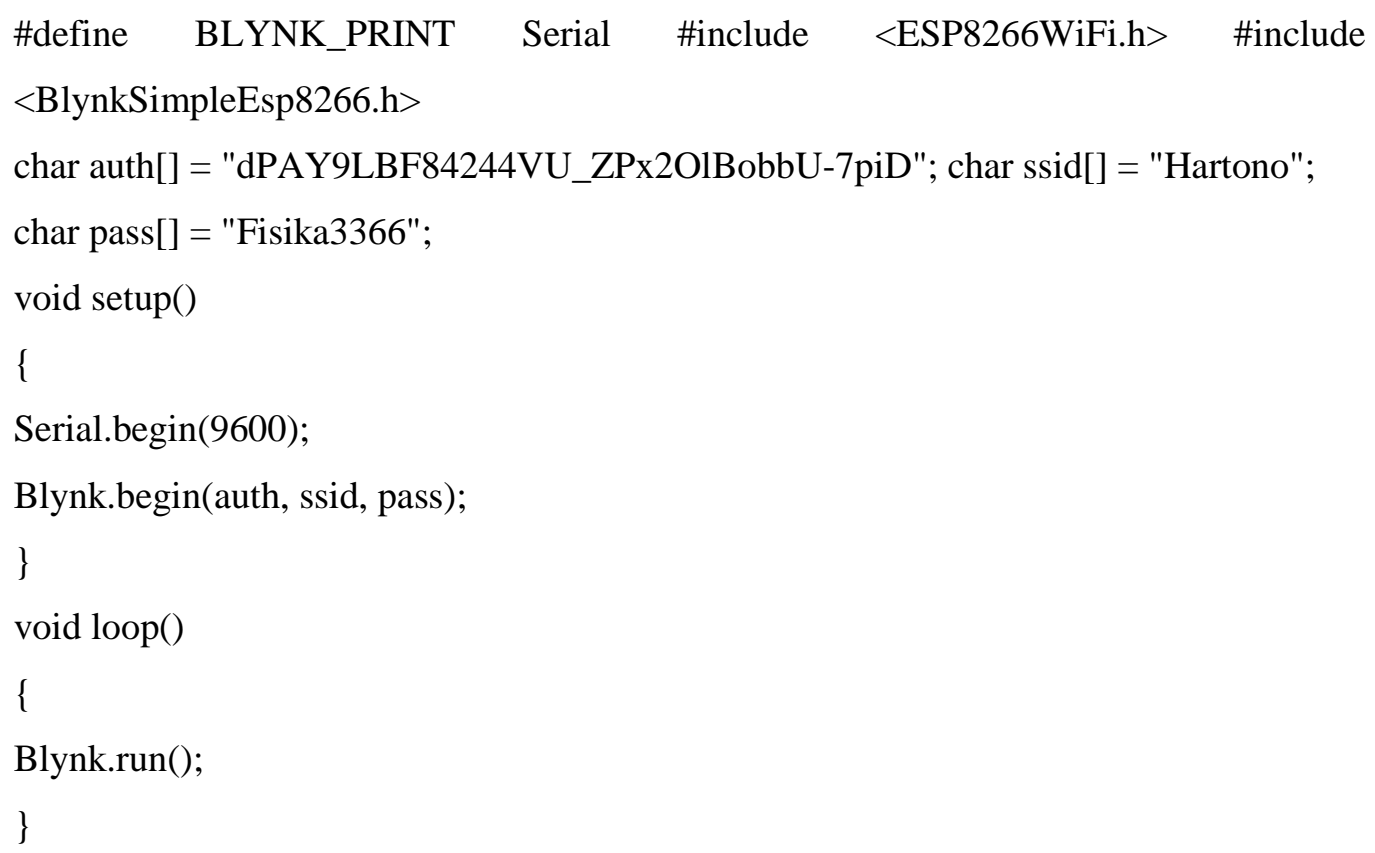

Based on the results of this test, the microcontroller works well and is already connected to the internet network, marked with the "blynk" on the serial monitor. 


\subsection{Relay Testing}

Relay testing is done by entering a simple program. This test is done to find out if the relay is working properly. Here are the details of the program:

int WATERPUMP $=13$; //motor pump connected to pin 13 int sensor $=8$; //sensor digital pin vonnected to pin 8 int val; //This variable stores the value received from Soil moisture sensor.

void setup() \{ pinMode(13,OUTPUT); //Set pin 13 as OUTPUT pin pinMode(8,INPUT); //Set pin 8 as input pin, to receive data from Soil moisture sensor.

//Initialize serial and wait for port to open:

Serial.begin(9600); // opens serial port, sets data rate to 9600 bps while (! Serial);// wait for serial port to connect. Needed for native USB Serial.println("Speed 0 to 255");

\}

void loop()

\{

if (Serial.available()) //loop to operate motor

\{

int speed = Serial.parseInt(); // to read the number entered as text in the Serial Monitor if $($ speed $>=0 \& \&$ speed $<=255)$

\{

analogWrite(WATERPUMP, speed);// tuns on the motor at specified speed

\}

$\mathrm{val}=$ digitalRead $(8) ; / /$ Read data from soil moisture sensor if(val == LOW $)$

\{

digitalWrite(13,LOW); //if soil moisture sensor provides LOW value send LOW value to motor pump and motor pump goes off

\}

else

\{

digitalWrite(13,HIGH); //if soil moisture sensor provides HIGH value send HIGH value to motor pump and motor pump get on 
delay(400); //Wait for few second and then continue the loop.

\section{\}}

After testing the relay is working properly, the results of this test are marked with live indicator LEDs.

\subsection{System Overall Testing}

The overall testing of the system is done by inserting a complete program into the microcontroller. After all the equipment and components are assembled according to the circuit image then the first step is to connect the input hose from the pump to the water source, then the output hose from the pump to the container / pot of the arugula plant, then the HW-390 sensor is plugged into the container / pot of the arugula plant. The last stage is a microcontroller connected to a 5VDC source. Here is the overall program of testing the system.

\#define BLYNK_PRINT Serial \#include <ESP8266WiFi.h> \#include <BlynkSimpleEsp8266.h> \#include <Wire.h>

\#include < LiquidCrystal_I2C.h> LiquidCrystal_I2C lcd(0x3F, 16, 2);

// You should get Auth Token in the Blynk App.

// Go to the Project Settings (nut icon).

char auth[] = "upQddpVMXLZ2m1E77rgdMpAONAKJy6nx";

// Your WiFi credentials.

// Set password to "" for open networks. char ssid[] = "Hartono"; char pass[] = "Fisika3366"; //WidgetLCD lcd(V2); int pompa= D2; void setup()

\{

// Debug console Serial.begin(9600); pinMode(D2,OUTPUT); Wire.begin(D4, D5); lcd.begin(); lcd.home();

Blynk.begin(auth, ssid, pass);

\}

void loop() \{

int sensor $=$ analogRead $(\mathrm{A} 0) ; \quad / /$ reads the value of the potentiometer $($ value between 0 and 1023) $\quad$ sensor $=\operatorname{map}($ sensor, 320, 650, 0, 100); Blynk.virtualWrite $\quad(V 1$, sensor); lcd.setCursor(0,0); lcd.print(" Kelemba = "); lcd.print(sensor); lcd.print(" \% "); if (sensor <=50) \{ digitalWrite(D2, HIGH); lcd.setCursor(0,1); lcd.print(" POMPA MATI "); Blynk.virtualWrite (V2,"POMPA MATI"); lcd.clear();

//lcd.print(0, 1, " POMPA HIDUP");

\} else \{ digitalWrite(D2, LOW); lcd.setCursor(0,1);

lcd.print(" POMPA HIDUP " $\quad$ ); Blynk.virtualWrite (V2,"POMPA

HIDUP"); //lcd.print(0, 1, "POMPA MATI

"); lcd.clear(); delay(1000); 
Blynk.run(); \}

\section{Conclusion}

Designing a system of tools in this study using the Esp8266 NodeMCU microcontroller. This device can only process 1 analog capacitive sensor. The sensor can measure soil moisture more accurately and corrosion resistant than resistive sensors. The pump will automatically flush the plant if the sensor detects moisture $<=50 \%$ and the pump dies if $>=50 \%$, and has been directly connected to the internet network. This tool system is also to monitor optimal soil moisture in arugula plants. The results of this study are very efficient and useful for the cultivation process as well as increasing crop yields.

\section{REFERENCES}

[1] E. Klein. "Arugula," Amerika: The American Prospect, 2008

[2] M. Miyazawa, T. Maehara and K. Kurose, "Composition of the essential oil from the leaves of Eruca sativa," Flavour and fragrance journal, vol. 17, no. 3, 2002.

[3] M. A. El-Missiry and A. M. El-Gindy, "Amelioration of alloxan induced diabetes mellitus and oxidative stress in rats by oil of Eruca sativa seeds," Annals of Nutrition and Metabolism, vol. 44, no. 3, 2000.

[4] T. Abdul, Komunikasi Data dan Jaringan Komputer, Jakarta: Salemba Teknika, 2007.

[5] B. Yifan and H. Wang. "The application of cloud compu-ting and the internet of things in agriculture and forestry," International Joint Conference, pp. 168-172, 2011.

[6] F. Ingelrest, G. Barrenetxea, G. Schaefer, M. Vetterli, O. Couach, and M. Parlange."Sensor- Scope: Application-specific sensor network for environmental monitoring". In ACM Transactions on Sensor. Networks (TOSN), Vol. 6, Issue 2, No. 17, 2010.

[7] Zhou, Zhongwei, and Z. Zhou. "Application of the internet of things in agriculture products supply chain management," In Control Engineering and Communication Technology, pp. 259-261, 2012.

[8] L, Sanbo, "Application of the Internet of Things Technology in Precision Agriculture Irrigation Systems," International Conference on IEEE, pp. 1009-1013, 2012.

[9] M. K. Gayatri, G. S. Anandha Mala, J. Jayasakthi, "Providing Smart Agricultural Solutions to Farmers for better yielding using IoT," TIAR, 2015.

[10] Lathal, A. Poojith, B. V. Amarnath, G. Reddy, V. Kumar. "Image Processing in Agriculture," IJIREEICE, Vol. 2, no. 6, 2014.

[11] M. E. Cartea, M. Francisco, P. Soengas, and P. Velasco, "Phenolic compounds in Brassica vegetables," Vol. 16, 2011.

[12] S. I. Hashmi, P. N. Satwadhar, R. R. Khotpal, H. W. Deshpande, K. A. Syed, and B. P. Vibhute., "Rapeseed meal nutraceuticals," JOB, Vol. 1, No, 2, 2010.

[13] E. D. Innoocenti, A. Pardossi, M. Tattini, and L. Guidi., "Phenolic compounds and antioxidant power in minimally processed salad," J. Food Biochem. Vol. 32, 2008.

[14] A. Koocheki, S. M. A. Razavi, and M. A. Hesarinejad., "Effect of extraction procedures on functional properties of Eruca sativa seed mucilage," Food Biophys, Vol. 7, 84-92, 2012. 
[15] M. V. Pulido, F. P. Capote, B. A. Sanchez, S. Saha, M. Philo, S. O. Cano, A. D. H. Balion, R. Font, and M. D. R. Celestino, "An Approach to the phytochemical profiling of Rocket (Eruca sativa Mill) Thell," J. Sci. Food Agric, 2013.

[16] H. Eller and A. Denoth, "A capacitive soil moisture sensor," Journal of Hydrology, vol. 185,1-4, 1996.

[17] Placidi, P., Gasperini, L., Grassi, A., Cecconi, M., \& Scorzoni, A., "Characterization of low-cost capacitive soil moisture sensors for IoT networks," Sensors, vol. 2, no. 12, 2020.

[18] Muzdrikah, F. Siti, M. S. Nuha, and F. A. Rizqi, "Calibration of capacitive soil moisture sensor," International Conference on Science and Technology (ICST) IEEE, 2018.

[19] M. F. Wicaksono, "Implementasi modul wifi NodeMCU Esp8266 untuk smart home," Komputika: Jurnal Sistem Komputer, vol. 6, no. 1, 2017.

[20] Z. Wan, Y. Song and Z. Cao, "Environment dynamic monitoring and remote control of greenhouse with ESP8266 NodeMCU," Information Technology, Networking, Electronic and Automation Control Conference (ITNEC), 2019. 